\title{
ANALISIS FAKTOR PENYEBAB KESULITAN BERHITUNG PERMULAAN PADA ANAK USIA 4-5 TAHUN DI TK AISYIYAH BUSTANUL ATHFAL 14 SURABAYA
}

\author{
Putri Maulida Hasanah ${ }^{1}$, Badruli Martati, Aristiana ${ }^{2}$, Prihatining Rahayu ${ }^{2}$ \\ Universitas Muhammadiyah Surabaya \\ E-mail : wuriainia10@gmail.com ${ }^{1}$, badruli.martati@ fkip.um-surabaya.ac.id² \\ aprahayu123@gmail.com ${ }^{3}$,
}

\begin{abstract}
ABSTRAK
Kemampuan berhitung permulaan pada anak usia 4-5 tahun merupakan konsep matematika yang perlu diberikan dan dikenalkan pada anak secara bertahap sesuai dengan tingkat penguasaan anak yaitu berupa bilangan, pola sebab akibat, geometri, dan pemecahan masalah. Sedangkan tingkat penguasaan pada anak usia 4-5 tahun terhadap kemampuan berhitung permulaan yang dibahas yaitu mengenal konsep bilangan 1-20, penjumlahan dan pengurangan secara sederhana. Faktor dari diri anak dan faktor dari lingkungan sekitar menjadi penyebab kesulitan kemampuan berhitung permulaan pada anak, maka diperlukan analisis faktor penyebab kesulitan berhitung permulaan pada anak usia 4-5 tahun. Tujuan penelitian ini adalah untuk menganalisa faktor penyebab kesulitan berhitung permulaan pada anak usia 4-5 tahun. Metode dalam penelitian ini adalah kualitatif deskriptif menggunakan observasi dan wawancara yang dilakukan melalui kuisoner google form dan media whatsapp. Hasil penelitian analisis faktor penyebab kesulitan berhitung permulaan pada anak usia 4-5 tahun di TK Aisyiyah Bustanul Athfal 14 Surabaya yaitu faktor internal atau dari diri anak ketika belajar sering tidak memperhatikan. Faktor eksternal atau dari lingkungan sekitar juga menjadi penyebab kesulitan berhitung permulaan, yaitu keluarga, teman dan guru, namun yang paling utama adalah dari keluarga. Dukungan dan motivasi dari kelurga sangat diperlukan bagi anak untuk membantu perkembangan anak dalam belajar kemampuan berhitung permulaan.
\end{abstract}

Kata kunci: analisis, kesulitan belajar, berhitung permulaan

\section{ABSTRACT}

The ability to count early in children aged 4-5 years is a mathematical concept that needs to be given and introduced to children gradually according to the child's level of mastery in the form of numbers, cause and effect patterns, geometry, and problem solving. While the level of mastery in children aged 4-5 years of initial numeracy skills discussed is knowing the concept of numbers 1-20, addition and subtraction in simple terms. Factors from children and environmental factors that cause difficulty in the initial numeracy ability in children, it is necessary to analyze the factors that cause difficulty in initiating counting in children aged 4-5 years. The purpose of this study was to analyze the factors that cause early counting difficulties in children aged 4-5 years. The method in this research is descriptive qualitative using observations and interviews conducted through qualitative google form and whatsapp media. The results of the study analyzed the factors that cause difficulty calculating the beginning of children aged 4-5 years in Aisyiyah Bustanul Athfal 14 Kindergarten Surabaya, namely internal factors or from children when learning often does not pay attention. External factors or from the surrounding environment also cause difficulties in calculating the starting point, namely family, friends and teachers, but the main thing is from family. Family support and motivation is needed by children to help the development of children in learning early numeracy skills.

Keywords: analysis, learning difficulties, preliminary arithmetic 


\section{PENDAHULUAN}

Taman kanak-kanak didirikan sebagai usaha mengembangkan seluruh kecerdasan anak dalam memenuhi kebutuhan pendidikan di sekolah. Kecerdasan adalah anugerah dari tuhan kepada manusia. Kecerdasan manusia dapat dipertahankan dan ditingkatkan dalam kualitas hidup melalui proses berpikir dan belajar secara terusmenerus. Setiap orang mengembangkan kecerdasan dengan beragam cara yang dikenal dengan Multiple Intelligence. Gardner mencetuskan Multiple Intelligence ada 9 jenis kecerdasan, yaitu kecerdasan musikal, kecerdasan kinestetik, kecerdasan spiritual, kecerdasan linguistik, kecerdasan visual-spasi, kecerdasan interpersonal, kecerdasan intrapersonal, kecerdasan naturalis dan kecerdasan logika matematia (Madyawati, 2017:18).

Kecerdasan logika matematika merupakan kecerdasan dalam menggunakan angka dan logika. Seseorang anak yang berkecerdasan logika matematika ini umumnya mampu mengenal waktu dan prinsip sebab-akibat, mampu mengamati objek dan mengerti fungsi dari obek tersebut, pandai dalam pemecahan masalah yang menuntut pemikiran logis, serta mampu mengenal dan mengerti konsep berhitung.
Demikian juga untuk memahami konsep berhitung pada anak usia dini haruslah melalui berbagai faktor, salah satunya yaitu faktor pendidikan (Madyawati, 2017:22).

Pendidikan merupakan faktor pendukung adanya kemajuan dalam perkembangan manusia. Oleh karena itu proses perkembangan manusia dimulai sejak dalam kandungan ibunya sampai memasuki usia dewasa. Menjadikan seorang individu yang sesuai dengan kegiatan sadar dan terencana untuk melaksanakan proses pembelajaran, yang berlangsung untuk mengembangkan potensi yang ada didalam diri peserta didik sehingga peserta didik mampu memaksimalkan setiap kompetensi yang ada pada dirinya yang akan menjadikan lebih baiknya kualitas individu. Maka perlu adanya lembaga pendidikan yaitu mulai dari jenjang pendidikan dasar hingga pendidikan lanjutan. Tercapainya pendidikan dasar melalui rangsangan atau stimulus.

Stimulasi tersebut bisa diperoleh melalui PAUD. Pendidikan Anak Usia Dini adalah jenjang pendidikan sebelum pendidikan dasar yang berupaya memberikan pembinaan kepada anak 0-6 tahun yang dilakukan melaui pemberian rangsangan pendidikan untuk membantu pertumbuhan dan perkembangan jasmani serta rohani 
anak agar siap masuk ke pendidikan lebih lanjut, upaya mempersiapkan generasi berikutnya yaitu pendidikan anak usia dini, yang kegiatannya untuk melatih dan mengembangkan berbagai kecerdasan yang dimiliki anak dan mengembangkan diri anak secara menyeluruh, meliputi, bidang fisik-motorik, intelektual atau kognitif, norma-agama, sosialemosional, bahasa, kreativitas atau seni. Salah satu aspek yang perlu dikembangkan adalah perkembangan kognitif.

Tahap perkembangan kognitif anak TK dalam pembelajaran dapat melalui kegiatan mengenal konsep bilangan dan menyebutkan lambang bilangan, membilang, membandingkan, mengurutkan, mengenal operasi bilangan dan kemampuan berhitung permulaan. Pengenalan konsep kemampuan berhitung permulaan sangat penting untuk dikuasai anak, sebab menjadi dasar bagi anak untuk menguasai konsep-konsep matematika selanjutnya di jenjang pendidikan. Kemampuan berhitung permulaan, akan mendorong setiap anak untuk mengembangkan kemampuan dan karakteristik kognitif yang penting dimulai dari lingkungan terdekat. Sejalan dengan perkembangan kognitif kemampuan anak akan meningkat ke tahap kemampuan berhitung permulaan, yaitu berhubungan dengan pejumlahan dan pengurangan, juga konsep lebih 118 banyak dan lebih sedikit (Susanto, 2012:98).

Proses pembelajaran kemampuan berhitung permulaan di lembaga pendidikan anak usia dini sangat bermanfaat bagi peserta didik untuk membangun proses berpikir yang cakupannya sangat luas dan menggunakan berbagai metode belajar, agar anak dapat dengan mudah memahami konsep kemampuan berhitung permulaan. Pembelajaran kemampuan berhitung permulaan dapat diberikan misalnya pada pengenalan bilangan, konsep lebih banyak dan lebih sedikit, juga konsep yang berhubungan dengan pejumlahan dan pengurangan.

Pembelajaran disekolah di TK Aisyiyah Bustanul Athfal 14 Surabaya umumnya sama seperti sekolah TK lainnya, namum untuk kondisi kemampuan berhitung permulaan pada anak usia 4-5 tahun nampaknya belum berhasil mengatasi kesulitan-kesulitan belajar yang dialami anak. Untuk-masalah kesulitan belajar kemampuan berhitung permulaan pada anak seringkali kurang mendapat perhatian dari guru. Tidak sedikit guru yang mengabaikan perkembangan siswanya, misalnya guru hanya memberikan perhatian kepada anak ketika mereka ribut, tidak memperhatikan atau membuat masalah. Gejala-gejala awal yang ditunjukkan anak saat mengalami kesulitan tidak diperhatika guru, 
sehingga kesulitan semakin parah dan mengganggu proses belajar pada anak. Untuk itu guru perlu untuk memperhatikan perkembangan setiap anak.

Dalam kondisi tersebut tidak hanya guru saja yang harus berperan, namun dengan bantuan dari orang tua maupun lingkungan sekitar perlu mengupayakan bantuan dan pendampingan agar anak yang mengalami kesulitan kemampuan berhitung permulaan segera mendapatkan penanganan yang tepat. Salah satu upaya yang dilakukan adalah dengan melakukan analisis kesulitan kemampuan berhitung permulaan, melalui analisis tersebut maka akan diketahui pada aspekaspek mana saja letak kesulitan kemampuan berhitung permulaan anak. Faktor penyebab kesulitan berhitung permulaan yang dialami oleh setiap anak dapat disebabkan oleh faktor internal pada diri anak yang meliputi faktor fisik maupun intelektual, dan faktor eksternal yang meliputi lingkungan keluarga dan sekolah.

Salah satu bentuk kesulitan berhitung permulaan yaitu kesulitan mengenali angka, ada anak yang belum mengenal beberapa angka dengan baik, atau bahkan sebagian besar bentuk angka. Anak seringkali mengalami kesulitan dalam membedakan angka dan menuliskan angka, seperti terbalik menuliskan lambang bilangan 3, 4, 5, 6 dan 9 . Hal tersebut terlihat pada saat anak mendapatkan pembelajaran penjumlahan dan pengurangan, kemudian mereka menuliskan jawaban dari penjumlahan dan pengurangan di buku masingmasing.

$$
\text { Berdasarkan rendahnya }
$$

kemampuan berhitung permulaan tersebut, guru harus berperan aktif dan mengetahui pada bagian mana anak mengalami kesulitan kemampuan berhitung permulaan pada anak. Kesulitan yang dialami oleh anak sangat beragam dan satu anak dengan anak yang lain kemungkinan akan mengalami kesulitan yang berbeda. Berdasarkan kondisi tersebut, maka penelitian ini berjudul "Analisis Faktor Penyebab Kesulitan Berhitung Permulaan pada anak usia 4-5 tahun di TK Aisyiah Bustanul Athfal Surabaya"

\section{REFERENSI TEORITIS}

\section{Kecerdasan Logika Matematika}

Kecerdasan logika matematika merupakan kecerdasan dalam menggunakan angka dan logika, antara lain yaitu memperkaya pengalaman berinteraksi dengan konsep matematika, eksplorasi pikiran melalui diskusi, mengenal bilangan melalui lagu, mengenal bentuk geometri (Madyawati, 2017:22).

Setiap individu berbeda antara satu dengan yang lainnya, baik dalam mengembangkan pengetahuan, sikap maupun keterampilan, sehingga setiap 
individu memiliki kecepatan belajar yang berbeda-beda. Berdasarkan hal tersebut, anak perlu mendapat kesempatan untuk mengembangkan aspek kecerdasan logika matematika. Menurut Gadner dalam buku Asmawati karakteristik kecerdasan logika matematika yaitu, dapat mengurutkan dan mengelompokkan benda, mulai tertarik pada angka, dapat mengikuti tiga perintah secara spontan, telah berminat pada penjumlahan. Dapat disimpulkan bahwa anak mampu mengklasifikasikan dan menata benda secara berurutan melalui objek nyata berdasarkan bentuk, warna dan ukuran.

Sedangkan menurut Campbell dalam buku Asmawati karakteristik kecerdasan logika matematika mempunyai ciri-ciri sebagai berikut, mampu mengenal konsep waktu dan sebab akibat, mampu memahami pola, mampu memecahkan masalah sederhana. Jadi kecerdasan logika matematika yang dapat dikembangkan adalah mengenal pola, konsep waktu, sebab akibat dan memecahkan masalah sederhana (Asmawati, 2017:138-140).

\section{Perkembangan Anak Usia Dini}

Perkembangan adalah suatu proses yang pasti di alami oleh setiap individu yang berhubungan dengan kematangan seseorang. Ketika kematangan belum tiba, maka anak sebaiknya tidak dipaksa untuk meningkatkan ke tahap berikutnya. Salah satunya yaitu perubahan mental yang secara bertahap dan dalam waktu tertentu, dari kemampuan tingkat sederhana menjadi kemampuan tingkat yang lebih tinggi, misalnya pada kecerdasan maupun tingkah laku. (Susanto, 2012:21).

Pada dasarnya, prinsip perkembangan anak:

1. Anak belajar dengan baik ketika kebutuhannya dapat terpenuhi dan merasa aman serta nyaman dalam lingkungan sekitarnya.

2. Anak akan belajar secara terusmenerus dan bertahap, mulai dari membangun pemahaman tentang sesuatu, salah satunya yaitu menemukan suatu konsep.

3. Anak juga akan belajar melalui interaksi soasial yang ada di lingkungan sekitarnya, baik dengan sesama teman sebayanya maupun orang yang lebih dewasa.

4. Motivasi belajar anak akan mempengaruhi minat dan bakat

5. Setiap individu anak terdapat perbedaan dalam perkembangan dan gaya belajar.

6. Proses belajar anak dimulai dari sesuatu yang sederhana ke kompleks, dari yang konkret ke abstrak, dari Gerakan ke bahasa, dan juga dari diri sendiri ke interaksi teman sebaya atau orang lain. 
Proses perkembangan belajar anak usia dini pada di dasari oleh dua teori belajar, yaitu behaviorisme yang menekankan hasil dari pada proses belajar, sedangkan konstruktivisme lebih menekankan pada proses belajarnya dari pada hasil. Sehingga kedua aliran tersebut memiliki karakteristik yang berbeda (Latif, 2013:73).

\section{Kemampuan \\ Permulaan}

Menurut

Berhitung

Munandar

kemampuan adalah suatu tindakan dalam melakukan proses dan latihan sehingga memberikan sebuah hasil. Seseorang dapat melakukan sesuatu karena adanya kemampuan yang dimilikinya. Dalam pandangan Munandar, kemampuan merupakan potensi seseorang yang dibawa sejak lahir yang disertai dengan pemberian stimulus dengan adanya pembiasaan dan latihan. Senada dengan Munandar, Robin dalam buku Susanto juga menyatakan bahwa kemampuan adalah kapasitas berbagai tugas dalam suatu pekerjaan tertentu. Berdasarkan menurut beberapa teori, kemampuan merupakan suatu daya yang dihasilkan dari pembawaan dan juga latihan yang mendukung individu dalam menyelesaikan tugasnya.

Berhitung adalah dasar dari beberapa ilmu yang digunakan dalam setiap kehidupan manusia. Aktivitas manusia tidak terlepas dari peran matematika di dalamnya, mulai dari penjumlahan, pengurangan, pembagian sampai perkalian. Berdasarkan pengertian tersebut, maka kemampuan berhitung bagi manusia sangatlah penting sehingga perlu diajarkan sejak dini dengan berbagai media dan metode yang tepat juga menarik (Susanto, 2012:97-98). Media dan metode yang tepat dalam pembelajaran berhitung permulaan bagi anak usia dini sangatlah diperlukan. Pada masa anak usia dini, mereka berada pada tahap berhitung permulaan yaitu anak berhitung dengan benda-benda yang ada disekitarnya mulai dari lingkungan terdekatnya dan dengan situasi yang menyenangkan atau bisa juga dengan bermain.

Menurut Susanto (2012:100-

104), tahapan dan prinsip kemampuan berhitung permulaan:

\section{Tahap Pengertian}

Tahap ini anak berekspresi dalam menghitung seluruh benda yang dapat dihitung dan yang dapat dilihatnya. Kegiatan berhitung ini juga harus disesuaikan dengan usia anak sehingga akan dapat dipahami dan dikuasai oleh anak. Pada tahap ini guru harus bisa memberikan kegiatan pembelajaran yang menarik dan berkesan sehingga akan membuat anak semangat dan merasa bosan.

2. Tahap Peralihan

Tahap ini diberikan apabila tahap pengertian sudah dapat dikuasai anak dengan baik, misalnya pada saat anak mampu 
menghitung kesesuaian antara benda yang dihitung dan bilangan yang disebutkan. Sehingga pada tahap ini anak mulai memahami.

3. Tahap Lambang

Tahap dimana anak sudah dapat diberikan kesempatan menulis sendiri, yaitu biasanya berupa konsep lambang bilangan, konsep penjumlahan dan pengurangan, pengenalan berbagai bentuk geometri dan kegiatan berhitung permulaan lainnya.

Berdasarkan prinsip kemampuan berhitung permulaan konsep matematika yang perlu diberikan dan dikenalkan pada anak secara bertahap sesuai dengan tingkat penguasaan anak yaitu berupa bilangan, pola sebab akibat, geometri, dan pemecahan masalah. Sedangkan tingkat penguasaan tahapan adalah tingkat pemahaman konsep, tingkat menghubungkan konsep konkret dengan lambang bilangandan tingkat lambang bilangan ketiga penguasaan tahapan tersebut dimulai dari konsep matematika, kemudian menghubungkan benda-benda nyata dengan lambang bilangan dan anak akan memahami lambang bilangan.

Prinsip dalam berhitung permulaan dikenalkan melalui media-media kreatif maupun media permainan, beberapa prinsip tersebut yaitu:

1. Dimulai dari menghitung benda
2. Berhitung dari yang mudah ke yang sulit

3. Anak dapat berperan aktif dan diimbangi dengan pemberian rangsangan untuk menyelesaikan masalah

4. Kegiatan pembelajaran yang menyenangkan

5. Menggunakan Bahasa yang mudah dipahami oleh anak dan memberikan contoh-contoh sederhana

6. Dikelompokkan sesuai dengan tahapan usiannya

7. Memberikan evaluasi dari awal hingga akhir kegiatan

\section{Kesulitan Belajar pada Anak Usia} Dini

Menurut Djamarah (2008:8) Belajar merupakan serangkaian kegiatan jiwa dan raga dalam memperoleh suatu perubahan tingkah laku, sebagai hasil dari pengalaman individu dalam berinteraksi dengan lingkungan, baik menyangkut aspek kognitif, afektik maupun psikomotor. Sehingga belajar adalah suatu proses usaha yang dilakukan individu untuk memperoleh suatu perubahan tingkah laku secara keseluruhan. Faktorfaktor yang mempengaruhi belajar anak dapat dibedakan menjadi dua macam, yaitu faktor internal dan faktor eksternal. Kedua faktor tersebut saling mempengaruhi satu sama lain dalam proses individu anak sehingga menentukan kualitas belajar. 
1. Faktor Internal

Faktor internal anak meliputi kekurangmampuan psiko-fisik, yaitu: bersifat kognitif seperti intelegensi anak, besifat afektif emosi dan sikap, bersifat psikomotor seperti terganggunya alat indera pengelihatan dan pendengaran.

2. Faktor Eksternal

Faktor eksternal anak meliputi semua situasi dan kondisi lingkungan sekitar yang tidak mendukung aktivitas belajar anak. Diantaranya: lingkungan keluarga seperti tidak harmonisnya hubungan orang tua, lingkungan masyarakat seperti teman bermain yang nakal, dan lingkungan sekolah seperti kondisi guru dan fasilitas belajar yang tidak memadai

\section{METODE PENELITIAN}

Jenis penelitian yang digunakan yaitu penelitian kualitatif, desain peneliltian yang digunakan adalah deskriptif. Tempat penelitian dilak dilaksanakan di lembaga pendidikan TK Aisyiyah Bustanul Athfal 14 Surabaya. Sedangkan waktu penelitian dilakukan pada semester genap tahun ajaran 2019/2020. Kegiatan penelitian ini diawali melakukan perizinan melalui media sosial whatsapp yang dilakukan pada bulan April 2020. Kelompok yang dipilih sebagai subyek penelitian dalam analisis kemampuan berhitung permulaan yaitu kelompok A yang masingmasing kelas terdapat 15 anak. Terdapat dua (2) anak yang mengalami kesulitan berhitung permulaan yaitu satu (1) anak di kelompok A2 dan satu (1) anak di kelompok A3.

Sumber data dalam penelitian ini adalah subjek yang memiliki informasi dan kejelasan tentang bagaimana data tersebut diambil, sumber data tersebut dibagi menjadi 2 yaitu data primer dan data sekunder. Menurut Umi Narimawati (2008:98) data primer adalah data yang diambil dari sumber pertama dan dapat diambil melalui narasumber atau responden dengan wawancara, dll. Berdasarkan pengertian tersebut, pada penelitian ini sumber data primer adalah guru TK A di TK Aisyiyah Bustanul Athfal 14 Surabaya. Sedangkan menurut Sugiyono (2008:402) data sekunder adalah sumber data yang diperoleh dengan cara membaca dan memahami melalui media yang bersumber pada buku, dokumen dll. Bersadarkan pengertin tersebut sumber data sekunder dalam penelitian ini diperoleh dari catatan peserta didik selama pembelajaran disekolah.

Teknik pengumpulan data yang digunakan dalam penelitian ini merupakan kuisoner atau angket dan observasi. Menurut Sugiyono (2010:274) triangulasi dalam pengujian kreadibilitas diartikan sebagai pengecekan data dari 
berbagai sumber dengan berbagai cara dan berbagai waktu. Triangulasi data dapat dibagi menjadi 3 yaitu: triangulasi sumber, triangulasi teknik dan triangulasi waktu. Dalam penelitian ini peneliti menggunakan triangulasi sumber dan triangulasi teknik.

Penelitian kualitatif deskriptif data menggunakan "Reduksi Data", apabila data yang diperoleh dari lapangan jumlahnya cukup banyak, maka perlu dicatat secara teliti dan rinci. Perlu dilakukan analisis data melalui reduksi data. Mereduksi data berarti merangkum, memilih hal-hal pokok dan fokus pada hal yang penting. Dengan demikian data yang telah direduksi akan memberikan gambaran yang lebih jelas dan mempermudah peneliti untuk melakukan pengumpulan data selanjutnya. 


\section{HASIL PENELITIAN}

Pengambilan data yang dilakukan dalam penelitian ini yaitu mengenai kesulitan berhitung permulaan pada anak usia 4-5 tahun, yang dilakukan di TK Aisyiyah Bustanul Athfal 14 Surabaya dengan pembagian kuisoner kepada guru kelas dan orang tua. Untuk guru kelas peneliti memberikan kuisoner berisikan tentang kesulitan berhitung permulaan ketika disekolah, sedangkan kuisoner untuk orang tua, peneliti membagikan kuisoner yang berisikan tentang kesulitan belajar anak ketika dirumah, dari hasil kuisoner antara guru dan orang tua maka diperoleh data dari 2 anak kelompok A yang mengalami kesulitan-kesulitan berhitung permulaan,

1. Kesulitan berhitung permulaan yang dialami oleh DKP kelas A3

Berdasarkan hasil kuisoner yang didapatkan, DKP mengalami kesulitan berhitung permulaan yaitu:

a. Belum mampu menyebutkan urutan bilangan 1-20, DKP pada dasarnya mampu menyebutkan urutan bilangan 1-10 dengan lancar, namun ketika berhitung dari 11-20 masih belum lancar dan terkadang harus dengan bantuan guru.

b. Belum mampu menyebutkan urutan bilangan 20-1, DKP masih kesulitan ketika menyebutkan urutan bilangan 20-1.

c. Belum mampu menunjukkan urutan bilangan 1-20, DKP seringkali tertukar ketika menunjukkan 6 dan 9, 16 dan 19.

d. Belum mampu menuliskan urutan bilangan 1-20, ketika DKP mendapatkan tugas menulis, DKP sering terbalik menuliskan angka 3, 6, 9, 16 dan 19.

e. Belum mampu menyebutkan bilangan sebelum dan sesudah secara acak, DKP belum bida menyebutkan bilangan sebelum dan sesudah secara acak, misalnya sebelum 5 adalah 4 , ataupun sesudah 5 adalah 6 .

f. Belum mampu mengenal lambang bilangan 1-20 dengan benda, DKP sering salah saat mengerjakan lembar aktivitas mengenal lambang bilangan dengan benda maupun secara langsung.

g. Belum mampu menjawab soal penjumlahan dan pengurangan, penjumlahan dan pengurang yang dimaksud adalah yang jawabannya tidak lebih dari 20. DKP masih sering mengalami kesulitan dalam menjawab soal penjumlahan dan pengurangan. Hasil kuisoner yang diisi oleh ayah dari Dimas juga menghasilkan deskripsi tentang faktor penghambat dalam berhitung permulaan, yaitu DKP merupakan anak yang aktif dan 
kadang susah untuk di kendalikan, cenderung hanya mengandalkan pembelajaran ketika disekolah, karena orang tua DKP sudah berpisah dan DKP tinggal dengan ayahnya. Pembelajaran yang dilakukan Dimas dirumah yaitu mengenal konsep bilangan 1-20, ketika DKP mengalami kesulitan belajar saat dirumah, ayahnya terkadang membiarkannya dan sesekali sampai mencubit DKP.

2. Kesulitan berhitung permulaan yang dialami oleh IFZ Kelas A2

Berdasarkan hasil kuisoner yang didapatkan, IFZ mengalami kesulitan belajar berhitung permulaan, yaitu:

a. Belum mampu menyebutkan urutan bilangan 1-20, IFZ pada dasarnya mampu menyebutkan urutan bilangan 1-20 secara keseluruhan, namun terkadang harus dengan bantuan guru.

b. Belum mampu menyebutkan urutan bilangan 20-1, IFZ masih kesulitan ketika menyebutkan urutan bilangan 20-1, dan terkadang masih terbalik dan ada angka yang dilompati. Misalnya, sebelum bilangan 15 adalah 14, namun IFZ terkadang langsung menyebutkan bilangan 13 .

c. Belum mampu menunjukkan urutan bilangan 1-20, IFZ seringkali tertukar ketika menunjukkan 6 dan 9, 16 dan 19.

d. Belum mampu menuliskan urutan bilangan 1-20, ketika IFZ mendapatkan tugas menulis, DKP sering terbalik menuliskan angka 3, 6, 9, 16 dan 19.

e. Belum mampu mengenal lambang bilangan 1-20 dengan benda, ketika IFZ mengerjakan lembar aktivitas masih sering salah dalam mengenal lambang bilangan baik secara langsung maupun dengan benda.

f. Belum mampu menjawab soal penjumlahan dan pengurangan, penjumlahan dan pengurang yang dimaksud adalah yang jawabannya tidak lebih dari 20. IFZ masih sering mengalami kesulitan dalam menjawab soal penjumlahan dan pengurangan. Hasil kuisoner yang diisi oleh ibu dari IFZ menghasilkan deskripsi tentang faktor penghambat dalam berhitung permulaan, yaitu Irdina kesulitan memahami konsep kemampuan berhitung permulaan, meskipun saat belajar dirumah Irdina selalu didampingi, didukung dengan fasilitas media pendukung dan pemberian reward dalam belajar, Ibu IFZ masih merasa IFZ kesulitan dalam kemampuan berhitung permulaan. Bentuk motivasi yang diberikan ibu Irdina kepada Irdina saat mengalami kesulitan belajar adalah dengan merayu dan memberi 
semangat bahwa dia mampu dan lebih bisa dari teman-temannya. Sedangkan untuk upaya ibu Irdina dalam mengatasi masalah kesulitan belajar ialah dengan rutin mendampingi belajar dan sesekali belajar sambil bermain.

\section{PEMBAHASAN}

A. Analisis faktor penyebab kesulitan kemampuan berhitung permulaan yang dialami anak usia 4-5 tahun di TK Aisyiyah Bustanul Athfal 14 Surabaya

Analisis faktor penyebab kesulitan kemampuan berhitung permulaan pada anak dilaksanakan dengan menganalisis hasil dari kuisoner yang telah dibagikan. Setelah dilakukan analisis dapat diketahui bahwa penyebab kesulitan kemampuan berhitung permulaan disebabkan oleh faktor internal dan faktor eksternal.
1..Faktor penyebab kesulitan kemampuan berhitung permulaan secara internal

Kurangnya minat belajar dari diri anak: pembelajaran pada anak usia 4-5 tahun umumnya menyukai belajar sambil bermain, maka dari itu sekolah terutama guru harus bisa menciptakan suasana belajar mengajar yang menyenangkan, menyediakan bebagai media yang sesuai untuk membantu anak mengenal konsep kemampuan berhitung permulaan, sehingga tidak membosankan untuk anak. Metode dan media yang digunakan di TK Aisyiyah Bustanul Athfal 14 Surabaya saat ini belum bervariasi dan cenderung berpusat pada guru, sehingga anak kurang tertarik dalam kegiatan belajar kemampuan berhitung permulaan.

2. Faktor penyebab kesulitan kemampuan berhitung permulaan secara eksternal

\begin{tabular}{crr}
\multicolumn{2}{c}{ Kurangnya dukungan } \\
keluarga dalam & belajar
\end{tabular}
kemampuan berhitung permulaan: keluarga terutama orangtua merupakan faktor pendukung yang paling utama dalam keberhasilan anak dalam belajar, termasuk belajar kemampuan berhitung permulaan. Hal tersebut haruslah menjadi perhatian orangtua, karena banyak orangtua yang sibuk bekerja dan menyerahkan tanggung jawab sepenuhnya kepada pihak sekolah, bahkan sampai melakukan kekerasan fisik kepada anak, sehingga pembelajaran berhitung permulaan yang diperoleh anak dirumah kurang maksimal.

B. Upaya yang diberikan Guru dalam Mengatasi Kesulitan Kemampuan Berhitung Permulaan

Solusi yang diberikan guru dalam mengatasi kesulitan kemampuan berhitung permulaan yaitu, guru memberikan perhatian lebih atau khusus terhadap anak 
yang belum mengetahui konsep kemampuan berhitung permulaan, guru memberikan memotivasi kepada anak bahwa anak pasti bisa, guru memberikan jam tambahan bagi anak yang masih kesulitan berhitung permulaan, sehingga seluruh anak dapat mengetahui konsep berhitung permulaan. Bagi anak yang mengalami kesulitan belum mampu mengenali angka, guru dapat mengajarkan dengan berbagai metode, baik metode bermain sambil belajar, maupun menggunakan berbagai macam media belajar yang kreatif dan menarik.

\section{KESIMPULAN}

Berdasarkan hasil penelitian yang dilakukan peneliti di TK Aisyiyah Bustanul Athfal 14 Surabaya maka ditarik kesimpulan bahwa faktor penyebab kesulitan kemampuan berhitung permulaan pada anak usia 4-5 tahun di TK Aisyiyah Bustanul Athfal 14 Surabaya yaitu secara internal kurangnya minat belajar dari diri anak, sedangkan secara eksternal kurangnya dukungan keluarga dalam belajar kemampuan berhitung permulaan. Solusi yang diberikan guru dalam mengatasi kesulitan kemampuan berhitung permulaan yaitu, guru memberikan perhatian lebih atau khusus terhadap anak yang belum mengetahui konsep kemampuan berhitung permulaan, 128 guru memberikan memotivasi kepada anak bahwa anak pasti bisa, guru memberikan jam tambahan bagi anak yang masih kesulitan berhitung permulaan, sehingga seluruh anak dapat mengetahui konsep berhitung permulaan. Bagi anak yang mengalami kesulitan belum mampu mengenali angka, guru dapat mengajarkan dengan berbagai metode, baik metode bermain sambil belajar, maupun menggunakan berbagai macam media belajar yang kreatif dan menarik.

\section{DAFTAR PUSTAKA}

Arikunto, Suharsimi. (2006). Prosedur Penelitian Suatu Pendekatan Praktik. Jakarta: Rineka Cipta

Asmawati, Luluk. (2017). Konsep Pembelajaaran PAUD. Bandung: Remaja Rosdakarya

Djamarah, Syaiful Bahri (2008). Psikologi Belajar. Jakarta: Rineka Cipta

Latif, Mukhtar dkk. (2013). Orientasi Baru Pendidikan Ank Usia Dini teori dan aplikasi. Jakarta: Fajar interpratama Mandiri

Madyawati, Lilis. (2017). Strategi Pengembangan Bahasa Pada Anak. Jakarta: Kencana. 
Mulyasa, H E. (2017). Strategi

Pembelajaran

PAUD.

Bandung: Remaja Rosdakarya

Narimawati, Umi. (2008). Metode

Penelitian Kuantitatif dan

Kualitatif. Bandung: Agung

Media
Sugiyono. (2010). Metode Penelitian

Kuantitatif Kualitatif dan

$R \& D$. Bandung: Alfabeta

Susanto, Ahmad. (2012).

Perkembangan Anak Usia

Dini. Jakarta: Kencana Prenada Media Group 